\title{
Competitiveness analysis of forest products trade between Turkey and European Union countries
}

\author{
Henry Eric Magezi ${ }^{\mathrm{a}}$ (D), Taner Okan ${ }^{\mathrm{a}, *}$ (D)
}

\begin{abstract}
The study assessed the competitiveness of Turkey and European Union countries in the trade of forest products. The study covered a period from 2006 to 2016 and focused on three commodity groups with the following harmonized system (HS) codes; HS44: Wood and articles of wood, wood charcoal; HS47: Pulp of wood, or other fibrous cellulosic material, recovered (waste and scrap) paper or paperboard; and HS48: Paper and paperboard, articles of paper pulp, paper or paper board. To analyze the competitive (dis)advantage of Turkey in forest products trade with the European Countries, the Revealed Comparative Advantage Index, Relative Export Advantage Index, Relative Import Advantage Index, and the Relative Trade Index were used. In addition, Cross Relative Export Advantage and Cross Relative Import Advantage indicators were used to examine the competitiveness of Turkey and European Countries in forest products trade. The findings indicated that although Turkey's Relative Export Advantage Index has been improving from 2012, the Relative Import Advantage Index worsened during the same period hence a trade disadvantage compared to the European Union countries in recent years.

Keywords: Forest products trade, International competitiveness, Turkey, European Union
\end{abstract}

\section{Türkiye ve Avrupa Birliği ülkeleri arasındaki orman ürünleri ticaretinin rekabet analizi}

\begin{abstract}
Özet: Bu çalışmada, Türkiye ve Avrupa Birliği ülkelerinin orman ürünleri ticaretindeki rekabet edebilirliği analiz edilmiştir. Çalışma, 2006'dan 2016'ya kadar olan bir dönemde üç ayrı emtia grubu (HS44: Odun ve odun kömürü ürünleri, HS:47 Odun hamuru, lifli selülozik malzeme, atık, vb., HS48: Kağıt ve karton, kağıt hamuru, kâğıt ve karton ürünleri) baz alınarak gerçekleştirilmiştir. Türkiye'nin $\mathrm{AB}$ ülkeleriyle orman ürünleri ticaretinde rekabet edebilirliğini ortaya koymak için, Açıklanmış Karşılaştırmalı Üstünlük Endeksi, Göreli İhracat Avantajı Endeksi, Göreli İthalat Avantajı Endeksi ve Göreli Ticaret Avantajı Endeksi kullanılmıştır. Ayrıca, Türkiye ve $\mathrm{AB}$ ülkelerinin orman ürünleri ticaretindeki rekabet edebilirliğini incelemek için ülkeler arası Göreli İhracat Avantajı ve Göreli İthalat Avantajı göstergeleri kullanılmıştır. Bulgular, Türkiye'nin Göreli İhracat Avantajının 2012'den itibaren iyileşmesine rağmen, aynı dönemde Göreli İthalat Avantajının kötüleștiğini, dolayısıyla $\mathrm{AB}$ ülkelerine kıyasla son yıllarda ticari bir dezavantaj olduğunu göstermiștir.

Anahtar kelimeler: Orman ürünleri ticareti, Uluslararası rekabet, Türkiye, Avrupa Birliği
\end{abstract}

\section{Introduction}

The European Union (EU) is Turkey's most important trading partner by far, accounting for slightly more than half of its exports and slightly less than half of its imports. This has gone on to increase trade flows between these two trading partners. In 2016, Turkey ranked fifth as EU trade partner with 66,702 million Euros worth of exports to the EU and 78,005 million Euros worth of imports from the EU. Turkey ranks as the top fourth country that imports from the EU and ranks as the fifth leading exporter to the EU (Eurostat Comext, 2017).

This increase in trade flows between Turkey and the EU has also extended to the forest sector. This is not surprising as the trade of forest products is fundamental to the economies of developed countries and is quickly becoming an important factor in the economic growth of several developing countries. The increase in trade flows of forest products can be attributed to factors like income growth, and advancements in forestry practice, harvesting technologies, and transportation costs, and the increased bilateral trade relations between countries (Prestemon et al., 2003).

The Gross Domestic Product (GDP) value of the EU represents 27.87 percent of the world economy. Although the EU makes up only $6.9 \%$ of the world's population, its trade with the rest of the world accounts for $15.6 \%$ of global imports and exports (EU, 2018). This makes it paramount for countries to assess the international competitiveness of their different sectors to maximize the trade potential in the EU market.

One of the countries in dire need of this kind of assessment is Turkey concerning the EU. As one of the major players in the East, Turkey is widening and deepening co-operation among European countries in various key spheres. Among the pertaining aspects of this trade between Turkey and European countries are the forest resources and the trade of its products. As such, there is an urgency to re-

\footnotetext{
$\triangle$ a Istanbul University-Cerrahpasa, Faculty of Forestry, Department of Forestry Economics, 34473 Bahçeköy-İstanbul

@ * Corresponding author (İletişim yazarı): tokan@istanbul.edu.tr

$\checkmark \quad$ Received (Geliş tarihi): 07.10.2019, Accepted (Kabul tarihi): 29.11.2019
}

Citation (Atıf): Magezi, H.E., Okan, T., 2019. Competitiveness analysis of forest products trade between Turkey and European Union countries. Turkish Journal of Forestry, 20(4): 366-372. DOI: $10.18182 /$ tjf.630250 
think and analyze the foreign trade of Turkey and the EU in the forest products sector. For Turkey, the EU represents an expanded market to tap, so this paper aims to assess the competitiveness of Turkey and EU countries in the trade of forest products. In addition, we aimed to understand whether Turkey holds any comparative advantage over EU countries in forest products trade.

\subsection{Competitiveness and comparative advantage}

Competitiveness, in contrast to comparative advantage, is not rigorously outlined within the earlier economic literature. Hence, after the many attempts to define competitiveness over time, it has become to a certain extent an ambiguous concept (Siggel, 2006). As such, some authors tend to use the term interchangeably with comparative advantage, and others interpret it as an economy-wide characteristic.

Thornhill (1988) defines competitiveness as an ex-post concept that should ideally involve comparisons between countries concerning the efficiency of production. On the contrary, he defines comparative advantage as an ex-ante theoretical concept involving comparisons between countries and products. Prasad (2004) noted that the concept of comparative advantage helps to gauge the patterns of trade and specialization of countries in commodities that they have a competitive edge.

Deardorff (1998) observed that in general, the concept of comparative advantage could be defined as a country having a low relative cost good compared to other countries. However, in the context of trade, international competitiveness refers to a nation securing and maintaining an advantage in trade compared to the rest of the world (Bobirca and Miclaus, 2011).

When it comes to forest resources, Ok (2003) explains that a country with more forest endowments exhibits comparative advantage in their exports as compared to countries with lesser forest endowments. Uusivuori and Tervo (2002) also stated that a country with relatively richer forest assets would have larger net exports of forest products.

\subsection{Measurement of international competitiveness}

Durand and Giorno (1987) listed three basic criteria that a perfect measure of international competitiveness ought to satisfy. A perfect measure should encompass all the sectors exposed to competition (i.e., represent all trade goods subject to competition and only focus on those goods), it should include all the markets open to competition, and it must be constructed from data that is fully comparable internationally.

Maksymets and Lönnstedt (2016) explain that in practice, no available indicator satisfies all these criteria. Kovalčík (2011) highlights that due to the gaps in the data and other limitations, compromises need to be made at every stage, so any measure of competitiveness (at best) is a rough estimate. Krugman (1994) also noted that, even determining the "competitiveness" of a country is not that obvious and attempts to enhance it may be misguided, partly because of difference in the functioning of countries and corporations (companies pursuing unsustainable methods tend to withdraw out of business, yet countries don't stop to exist).
Siggel (2006) observes that it is common in the empirical trade literature to calculate comparative advantage using the Balassa (1965) index of 'Revealed Comparative Advantage' (RCA). This approach reflects the success in exporting countries relative to a worldwide standard. However, success in exports can be a consequence of subsidies or other incentives that may be provided, for instance by exchange rate misalignment. Such incentives justify competitiveness, but not comparative advantage. As such, Siggel (2006) concluded that the RCA index is an indicator of competitiveness rather than comparative advantage. He observed that the sole well-known measure that qualifies as an ideal indicator of comparative advantage is the Domestic Resource Cost (DRC) criterion. However, Vollrath and Huu Vo (1988) highlight the focus on only exports as the main shortcoming of Balassa's RCA index. In addition, Vollrath (1991) provided the Relative Trade Advantage (RTA) index, which takes into account both export and import statistics.

Since no available indicator satisfies to provide a conclusive assessment of a country's competitiveness, Sirgmets et al. (2019) conclude that indicators for competitiveness should be used in combination with other indicators to provide an assessment that is as complete as possible.

As such, various indices have been developed to assess international competitiveness and several authors have applied a combination of these indices while examining the international competitiveness of countries. For example, Fertö and Hubbard (2003) using the Relative Export Advantage (RXA), Relative Import Advantage (RMA), RTA, and Revealed Competitiveness (RC), analyzed the comparative advantage of the Hungarian agri-food sector relative to the EU from 1992-1998. Bojnec and Fertö (2009) also used RXA, RMA, and RTA indices to investigate the international competitiveness of agri-food sectors in eight Central and Eastern European and Balkan countries from 1995 to 2007. Y1lmaz (2003) employed the RCA, Comparative Export Performance (CEP), Trade Overlap (TO), and Export Similarity (ES) indices to examine the international competitiveness of the Turkish economy and the structure of specialization in trade in comparison with the five EU candidate countries Bulgaria, the Czech Republic, Hungary, Romania, Poland, and the EU/15.

\section{Materials and methods}

\subsection{Materials}

The study focuses on the forest products trade between Turkey and the EU members. All the 28 members of the EU as of Dec 2016 (EU-28) were considered for the study. These are Austria, Belgium, Bulgaria, Croatia, Cyprus, Czech Republic, Denmark, Estonia, Finland, France, Germany, Greece, Hungary, Ireland, Italy, Latvia, Lithuania, Luxembourg, Malta, Netherlands, Poland, Portugal, Romania, Slovakia, Slovenia, Spain, Sweden, and the United Kingdom.

The data set contained the annual imports and exports values from the trade of forest products between Turkey and the EU28 from the years 2006 to 2016 .

The main source of data was the UN Comtrade database (United Nations, 2017), for three commodity groups 
following the Harmonized System Codes (HS Code 2017). HS44: Wood and articles of wood, wood charcoal; HS47: Pulp of wood, or other fibrous cellulosic material, recovered (waste and scrap) paper or paperboard; and HS48: Paper and paperboard, articles of paper pulp, paper or paperboard. For consistency and uniformity, the data was converted into Euros.

\subsection{Methods}

\section{Balassa Index}

The RCA Index or Balassa [1965] Index is obtained from the formula below:

$$
B=\frac{X_{i j} / X_{r j}}{X_{i s} / X_{r s}},
$$

Where $X_{i j}$ is the volume or value of exports of product $i$ by country $j . \quad X_{r j}$ is the volume or value of exports of all products by country $\mathrm{j}$. $\mathrm{X}_{\text {is }}$ is the volume or value of exports of product $\mathrm{i}$ by all countries of the world (or region), and $\mathrm{X}_{\mathrm{rs}}$ is the total volume or value of world (region) exports of the product.

If RCA is greater than one, then there is a comparative advantage of the trade in the focal product. For this study, the world (region) was defined to represent the European Union.

\section{The relative export advantage}

RXA is calculated from formula (2) (Maksymets and Lönnstedt, 2016):

$$
R X A=\frac{X_{i j} / X_{r j}}{\left(X_{i s}-X_{i j}\right) /\left(X_{r s}-X_{r j}\right)} .
$$

An RXA index that exceeds 1 indicates that the country has an export advantage in the focal commodity. This is slightly different from the specification given by Vollrath (1991) where he equated RXA with RCA $(\mathrm{RXA}=\mathrm{RCA}=$ Balassa Index). However, the results of the two are not significantly different.

\section{The relative import advantage}

RMA is obtained from formula (3) (Vollrath, 1991):

$$
R M A=\frac{M_{i j} / M_{r j}}{\left(M_{i s}-M_{i j}\right) /\left(M_{r s}-M_{r j}\right)},
$$

Where $\mathrm{M}_{\mathrm{ij}}$ is the volume or value of imports of product $\mathrm{i}$ into country $\mathrm{j}, \mathrm{M}_{\mathrm{rj}}$ is the volume or value of imports of all products to country $\mathrm{j}, \mathrm{M}_{\text {is }}$ is the volume or value of imports of product $i$ to the $E U$ and $M_{r s}$ is the volume or value of the total EU imports.

Its interpretation is reverse to that of RXA. A value less than 1 indicates that a country has an import Advantage.

\section{Relative trade advantage}

A positive value of RTA is an indication of comparative advantage, $\mathrm{RTA}=0$ is a break-even point neither with trade advantage nor trade disadvantage and RTA $<0$ is an indication of comparative disadvantage (Vollrath, 1991).

RTA is then obtained from formula (4):

$$
R T A=R X A-R M A .
$$

In addition to the commonly used RC, RXA, and RMA indices, the study also used Cross-Country Indices of Relative Competitiveness to reveal relative competitiveness of Turkey relative to the $28 \mathrm{EU}$ countries since competitiveness is a relative measure.

\section{Cross relative competitiveness}

(CRC) is obtained using the Cross Relative Export Advantage (CRXA) and the Cross Relative Import Advantage (CRMA) (Maksymets and Lönnstedt, 2016).

$$
\text { CRXA }=\frac{X_{i j} / X_{r j}}{X_{i k} / X_{r k}}
$$

Where $X_{i j}$ is the volume or value of exports of product $i$ by country $j, X_{\mathrm{rj}}$ is the volume or value of exports of all products by country $\mathrm{j}, \mathrm{X}_{\mathrm{ik}}$ is the volume or value of exports of product $\mathrm{i}$ by country $\mathrm{k}$, and $\mathrm{X}_{\mathrm{rk}}$ is the volume or value of all exports of all products by country $\mathrm{k}$.

The index shows the ratio of a country's export share of a commodity in relation to that of a competitor in the target market.

A CRXA that exceeds 1 reveals that the country has an advantage in the export of the focal commodity compared to the competitor (Bobirca and Miclaus, 2011).

Similarly, CRMA is obtained from formula (6)

$$
\text { CRMA }=\frac{M_{i i} / M_{r j}}{M_{i k} / M_{r k}} .
$$

The interpretation of CRMA is also reverse to that of CRXA where a CRMA value less than 1 reveals a comparative advantage (Maksymets and Lönnstedt, 2016).

When CRXA and CRMA are compared in logarithmic form, they are symmetric at the origin. The CRC is calculated from formula (7):

$$
\ln C R C=\ln C R X A-\ln C R M A
$$

A CRC value greater than zero $(\operatorname{lnCRC}>0)$ shows that country $i$ is more competitive in the target market relative to competitor j (Maksymets and Lönnstedt, 2016).

\section{Results and discussion}

Turkey experiences disadvantage in the export of HS44, HS47 and HS48 products on the EU market with mean values of 0.42 and 0.41 for RCA and RXA respectively for the period from 2006 to 2016. However, both the values of RCA and RXA indices have been increasing over the past 
eleven years expect in 2012 where there was a fall in the progressive increase (Figure 1).

On the other hand, Turkey experienced an advantage in the import penetration of forest products until 2010. However, it has been experiencing an RMA index greater than 1 since 2012. This implies a relative import disadvantage in the trade of forest products. As a result, Turkey has been experiencing comparative trade disadvantage in forest products on the EU markets as the values of RTA index has been negative throughout the focus period of this study (Figure 1).

Generally, majority of the 28 countries experience a comparative advantage in trade of forest products on the EU market. Countries like Austria, Belgium, Croatia, Czech Republic, Estonia, Finland, Lithuania, Poland, Portugal, Romania, Slovakia, Slovenia, Sweden, Latvia have an average RCA greater than one over the study period from 2006-2016 (Table 1). Finland has the highest mean RCA in forest products trade in the EU with an index of 6.61 over the eleven years with its highest, 7.6 in 2015. This shows that it enjoys the greatest comparative advantage followed by Latvia with a mean RCA of 6.03 over the eleven years.

As with the RCA, majority of the EU countries experience a greater revealed export advantage of forest products to the EU market compared to Turkey with fourteen countries having a mean RXA of one and above. As with RCA, Finland has the highest average RXA of 7.19 ranging from 6.01 to 8.30 over the study period of eleven years (Table 1). On the other hand, Malta experiences the least mean RXA value of 0.02 over the eleven years. This shows that Malta has the greatest export disadvantage compared to even Turkey.

From Table 1, more than half of the 28 countries in the EU experience a mean RMA of one and above which is higher that of Turkey over the study period. This indicates that the majority of the EU members have a higher relative import disadvantage in importing forest products compared to Turkey with Estonia having the highest mean value of RMA at 2.04 over the study period. Luxembourg experiences the lowest mean value of RMA of 0.39 over the same period. This implies that Luxembourg experiences the highest RMA.

1,5

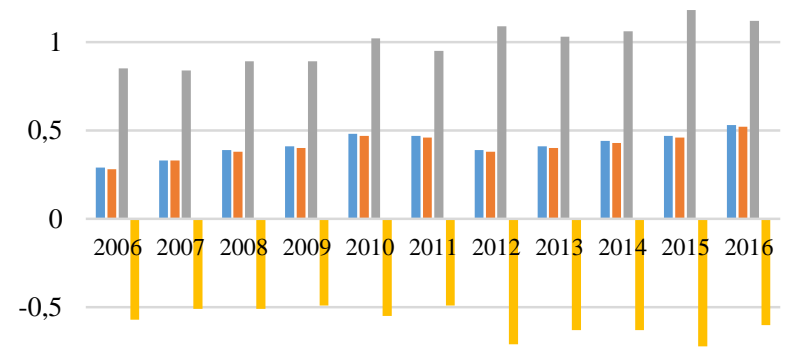

$\square \mathrm{RCA} \backsim \mathrm{RXA} \square \mathrm{RMA} \square \mathrm{RTA}$

Figure 1. Turkey's RCA, RXA, RMA and RTA in forest products trade with the EU
Table 1: Mean RCA, RXA, RMA, and RTA of EU countries in forest products trade

\begin{tabular}{lrrrr}
\hline Country & RCA & RXA & RMA & RTA \\
\hline Austria & 2.04 & 2.11 & 1.50 & 0.62 \\
Belgium & 1.02 & 1.02 & 1.17 & -0.15 \\
Bulgaria & 0.85 & 0.85 & 1.01 & -0.16 \\
Croatia & 1.58 & 1.59 & 1.50 & 0.09 \\
Cyprus & 0.04 & 0.04 & 0.73 & -0.69 \\
Czech & 1.21 & 1.21 & 1.09 & 0.12 \\
Denmark & 0.49 & 0.48 & 1.15 & -0.66 \\
Estonia & 3.87 & 3.90 & 2.04 & 1.86 \\
Finland & 6.61 & 7.19 & 1.08 & 6.10 \\
France & 0.69 & 0.67 & 0.95 & -0.28 \\
Germany & 0.96 & 0.95 & 0.97 & -0.02 \\
Greece & 0.20 & 0.20 & 0.90 & -0.69 \\
Hungary & 0.72 & 0.72 & 0.95 & -0.23 \\
Ireland & 0.13 & 0.13 & 0.37 & -0.24 \\
Italy & 0.75 & 0.73 & 1.14 & -0.41 \\
Latvia & 6.03 & 6.09 & 1.81 & 4.28 \\
Lithuania & 1.85 & 1.86 & 1.58 & 0.28 \\
Luxembourg & 0.32 & 0.31 & 0.39 & -0.08 \\
Malta & 0.02 & 0.02 & 0.45 & -0.44 \\
Netherlands & 0.54 & 0.52 & 0.83 & -0.31 \\
Poland & 1.63 & 1.66 & 1.38 & 0.27 \\
Portugal & 1.97 & 1.98 & 1.19 & 0.79 \\
Romania & 1.46 & 1.46 & 1.09 & 0.37 \\
Slovakia & 1.27 & 1.27 & 0.93 & 0.34 \\
Slovenia & 2.05 & 2.06 & 1.78 & 0.27 \\
Spain & 0.74 & 0.73 & 0.86 & -0.13 \\
Sweden & 3.27 & 3.55 & 0.94 & 2.61 \\
United Kingdom & 0.32 & 0.29 & 0.98 & -0.68 \\
Turkey & 0.42 & 0.41 & 0.99 & -0.58 \\
\hline & & & & \\
\hline
\end{tabular}

Thirteen EU countries have a positive mean RTA over the study period, which implies a comparative advantage in the trade of forest products. Of these, Finland and Latvia have the highest mean RTA with mean values of 6.10 and 4.28 respectively. On the other hand, 15 countries experience a negative mean RTA with Cyprus and Greece experiencing the highest trade disadvantage with a mean value of -0.69 . However, Germany with a mean RTA (0.02 ) over the eleven years indicates that it is close to breaking even although it is experiencing a trade disadvantage (Table 1).

Parallel to Turkey, majority of the EU countries experienced a fall in the comparative advantage indices during the same period between 2011 and 2013, which is post the economic crisis of 2008-2009. This could be to the fact that the economic crisis did not only affect the forest products sector but every other sector of these economies. As such, the total exports and imports of the countries were also affected during the economic crisis. In addition, since the comparative advantage indices do not capture such details, the effects may not be reflected in the indices since both the forest products trade flows and the total exports and imports decreased.

Turkey has a mean CRXA over six countries in the EU over the eleven years. It has an export advantage to the EU forest product market over United Kingdom (1.32), Malta (26.48), Luxembourg (1.36), Ireland (3.29), Greece (2.06), and Cyprus (11.86). On the view of cross relative import advantage, Turkey experiences a mean import advantage over half of the EU countries. This advantage is greatest over Latvia with a CRMA of 0.57 (Table 2). 
Table 2: Mean values of CRXA and CRMA

\begin{tabular}{lcc}
\hline Country & CRXA & CRMA \\
\hline Austria & 0.21 & 0.67 \\
Belgium & 0.41 & 0.86 \\
Bulgaria & 0.51 & 0.98 \\
Croatia & 0.27 & 0.67 \\
Cyprus & 11.86 & 1.41 \\
Czech & 0.35 & 0.92 \\
Denmark & 0.86 & 0.87 \\
Estonia & 0.11 & 0.49 \\
Finland & 0.06 & 0.94 \\
France & 0.61 & 1.05 \\
Germany & 0.44 & 1.02 \\
Greece & 2.06 & 1.11 \\
Hungary & 0.58 & 1.05 \\
Ireland & 3.29 & 2.78 \\
Italy & 0.56 & 0.88 \\
Latvia & 0.07 & 0.57 \\
Lithuania & 0.23 & 0.63 \\
Luxembourg & 1.36 & 2.53 \\
Malta & 26.48 & 2.21 \\
Netherlands & 0.77 & 1.18 \\
Poland & 0.26 & 0.73 \\
Portugal & 0.21 & 0.84 \\
Romania & 0.29 & 0.91 \\
Slovakia & 0.34 & 1.07 \\
Slovenia & 0.21 & 0.56 \\
Spain & 0.57 & 1.15 \\
Sweden & 0.13 & 1.06 \\
United Kingdom & 1.32 & 1.02 \\
\hline & &
\end{tabular}

Since the study aimed to reveal competitiveness of Turkey with EU countries concerning forests products trade, the natural logs of both CRXA and CRMA were calculated to make them symmetric at the origin and their difference was obtained to reveal the competitiveness of Turkey in trade of forest products with EU countries (Table 3).

Turkey generally is not competitive as the members of the EU when it comes to trade of forest products. The CRC of Turkey with 23 countries of EU in forest products trade on the European market is below zero.

In Table 3, results show that Turkey is more competitive than only Cyprus, Greece, Ireland, Malta and the United Kingdom where $\operatorname{lnCRC}$ is greater than zero. Of these countries, Malta with a mean of 2.43 over the focal period is the least competitive with Turkey in the forest products trade. On the other hand, Turkey is least competitive with Finland with a mean index of -2.68 over the focal period of the study.

The authors share the position of Puttock et. al (1993) that "The European market for forest products is mature, with growth paralleling increases in population". Growth in the market share for one supplier in a mature market must come at the expense of another supplier. Therefore, Turkey joining the EU is likely to improve its competitiveness in trade of forest products with EU countries.

This is in line with Mercenier and Yeldan (1997) who observed that the EU full membership for Turkey would be beneficial since it would lead to the removal of non-tariff barriers. It would be more beneficial for the Turkish economy to prefer a form of trade relations with the EU including the elimination of non-tariff barriers instead of only customs union.

Table 3. $\operatorname{lnCRC}$ of Turkey with EU countries in forest products trade

\begin{tabular}{|c|c|c|c|c|c|c|c|c|c|c|c|}
\hline Country & 2006 & 2007 & 2008 & 2009 & 2010 & 2011 & 2012 & 2013 & 2014 & 2015 & 2016 \\
\hline Austria & -1.55 & -1.45 & -1.32 & -1.05 & -1.05 & -1.06 & -1.36 & -1.17 & -1.11 & -1.13 & -0.9 \\
\hline Belgium & -1 & -0.8 & -0.74 & -0.63 & -0.62 & -0.57 & -0.86 & -0.76 & -0.73 & -0.84 & -0.63 \\
\hline Bulgaria & -0.83 & -0.65 & -0.35 & -0.17 & -0.52 & -0.56 & -0.97 & -0.87 & -0.95 & -0.95 & -0.64 \\
\hline Croatia & -0.85 & -0.81 & -0.74 & -0.58 & -0.64 & -0.72 & -1.16 & -1.16 & -1.14 & -1.16 & -0.99 \\
\hline Cyprus & 1.64 & 2.15 & 2.13 & 2.19 & 2.05 & 2.01 & 1.99 & 2.05 & 2.24 & 2.17 & 2.39 \\
\hline Czech & -1.22 & -1.12 & -0.95 & -0.87 & -0.86 & -0.82 & -1.08 & -0.96 & -0.98 & -1.01 & -0.84 \\
\hline Denmark & -0.21 & -0.05 & -0.05 & 0.01 & 0.09 & 0.15 & -0.12 & -0.03 & -0.04 & -0.07 & 0.06 \\
\hline Estonia & -1.67 & -1.49 & -1.49 & -1.32 & -1.35 & -1.41 & -1.7 & -1.58 & -1.56 & -1.61 & -1.46 \\
\hline Finland & -2.87 & -2.56 & -2.26 & -2.56 & -2.48 & -2.46 & -2.86 & -2.78 & -2.85 & -2.99 & -2.85 \\
\hline France & -0.78 & -0.62 & -0.51 & -0.44 & -0.39 & -0.35 & -0.7 & -0.57 & -0.6 & -0.66 & -0.5 \\
\hline Germany & -1.13 & -0.98 & -0.9 & -0.83 & -0.73 & -0.68 & -0.96 & -0.84 & -0.8 & -0.83 & -0.67 \\
\hline Greece & 0.66 & 0.74 & 0.84 & 0.79 & 0.74 & 0.61 & 0.27 & 0.52 & 0.53 & 0.47 & 0.67 \\
\hline Hungary & -0.76 & -0.67 & -0.55 & -0.52 & -0.52 & -0.49 & -0.73 & -0.62 & -0.61 & -0.63 & -0.4 \\
\hline Ireland & 0.13 & 0.24 & 0.32 & 0.34 & 0.25 & 0.31 & -0.09 & -0.04 & -0.01 & 0.19 & 0.18 \\
\hline Italy & -0.55 & -0.43 & -0.39 & -0.44 & -0.35 & -0.31 & -0.64 & -0.48 & -0.48 & -0.54 & -0.41 \\
\hline Latvia & -2.38 & -2.14 & -2.08 & -2.03 & -2.08 & -2.1 & -2.35 & -2.12 & -1.96 & -1.99 & -1.77 \\
\hline Lithuania & -1.24 & -1.13 & -0.99 & -0.84 & -0.93 & -0.9 & -1.17 & -1.1 & -1.04 & -1.1 & -0.91 \\
\hline Luxembourg & -0.92 & -0.77 & -0.63 & -0.47 & -0.51 & -0.44 & -0.77 & -0.63 & -0.67 & -0.69 & -0.51 \\
\hline Malta & 2.66 & 2.76 & 2.14 & 3.3 & 2.63 & 2.61 & 2.08 & 2.01 & 1.89 & 2.34 & 2.34 \\
\hline Netherlands & -0.67 & -0.47 & -0.36 & -0.38 & -0.36 & -0.26 & -0.53 & -0.43 & -0.43 & -0.52 & -0.33 \\
\hline Poland & -1.26 & -1.15 & -1.05 & -0.98 & -0.94 & -0.88 & -1.15 & -1.03 & -1.04 & -1.08 & -0.94 \\
\hline Portugal & -1.54 & -1.34 & -1.28 & -1.2 & -1.27 & -1.17 & -1.62 & -1.46 & -1.42 & -1.51 & -1.28 \\
\hline Romania & -1.19 & -1.08 & -0.9 & -0.82 & -1.01 & -1.06 & -1.53 & -1.41 & -1.35 & -1.29 & -0.96 \\
\hline Slovakia & -1.62 & -1.36 & -1.22 & -1.24 & -1.07 & -1.01 & -1.22 & -1.02 & -1.04 & -1.13 & -0.92 \\
\hline Slovenia & -1.26 & -1.09 & -1.02 & -0.97 & -0.84 & -0.82 & -1.13 & -0.97 & -0.99 & -0.98 & -1.02 \\
\hline Spain & -0.81 & -0.67 & -0.7 & -0.63 & -0.66 & -0.63 & -0.95 & -0.79 & -0.75 & -0.73 & -0.55 \\
\hline Sweden & -2.33 & -2.11 & -2.08 & -2.07 & -1.97 & -1.92 & -2.29 & -2.18 & -2.16 & -2.21 & -1.97 \\
\hline United Kingdom & 0.05 & 0.21 & 0.217 & 0.34 & 0.39 & 0.4 & 0.03 & 0.19 & 0.26 & 0.31 & 0.4 \\
\hline
\end{tabular}




\section{Conclusion}

This study assessed the competitiveness of Turkey and EU countries in the trade of forest products. The empirical findings revealed that Turkey has a comparative disadvantage compared to EU members in the EU market in the forest products sector. Generally, Turkey is not competitive as the members of the EU when it comes to trade of forest products. Turkey is only more competitive than Cyprus, Greece, Ireland, Malta, and the United Kingdom.

On the side of forest products imports, majority of the EU members have a higher relative import disadvantage in importing forest products compared to Turkey. While Turkey is experiencing improving RXA index, its relative import advantage index has been generally above one in the last five years. As such, the improving RXA is negatively counteracted by the worsening RMA index. For this reason, the relative trade advantage index of Turkey has been worsening in the last five years. Therefore, inward-looking measures should be taken to insure improving indices for the relative import advantage if Turkey is to have an advantage in the trade of forest products with the EU countries.

Although the trend of these indices is not definitive whether increasing or decreasing over the focal period of the study, it is important to note the indices of Turkey's competitiveness compared to the many EU members has been improving (tending towards to zero) in the last three to four years of the study. It is indicative that Turkey's forest products trade competitiveness is likely to increase even higher when Turkey joins the EU.

Even with all these findings, the study had some unaddressed issues that could be areas for examination in future research. The study considered the total of the HS44, HS47, and HS48 in the analysis. This leaves a gap for future research to study in detail the indices of these specific forest product groups.

However, this study provides interesting results that may help policymakers to obtain a clearer view on how to improve Turkey's forest products trade the EU

Turkey should take full advantage of the deepening bilateral trade relationship with the EU to serve as an instrument for the expansion of forest products trade. In addition, export promotion of forest products may play a significant role in supporting the country for the long run growth and improve the export competitiveness of the forest sector.

As such, export promotion schemes and incentives should be extended to exporters in promoting and expanding forest product exports to the EU market.

More effects should be applied in implementing Turkey's complete entry to the EU if Turkey is to maximize all its forest products trade. It would be more beneficial for the Turkish economy to prefer a form of trade relations with the EU including the elimination of non-tariff barriers instead of only customs union.

\section{Acknowledgement}

This article is a part of a Master's of Science thesis titled "Foreign Trade Analysis between Turkey and European Union Countries in Forest Products Sector" prepared at the Forestry Economics Department at the Institute of Graduate Studies, Istanbul University-Cerrahpasa.

\section{References}

Balassa, B., 1965. Trade liberalization and revealed comparative advantage. Manchester School of Economics and Social Studies, 33: 99-123.

Bobirca, A., Miclaus, P.G., 2011. A multilevel comparative assessment approach to international services trade competitiveness: The case of Romania and Bulgaria. International Journal of Humanities and Social Sciences, 1(3): $1-6$.

Bojnec, S., Fertö, I., 2009. Agro-food trade competitiveness of Central European and Balkan Countries. Food Policy, 34: 1725.

Deardorff, A.V., 1998. Benefits and costs of following comparative advantage. In University of Michigan, School of Public Policy, Research Seminar in International Economics Discussion Paper (No.423).

Durand, M., Giorno. C., 1987. Indicators of international competitiveness: Conceptual aspects and evaluation. OECD Economic and Studies, 9: 147-82.

EU, 2018. European Union. http://europa.eu/european-union/abouteu/figures/economy_en, Accessed: 25.07.2018.

Eurostat Comext, 2017. European Commission, DirectorateGeneral for Trade 2017, European Union, Trade with Turkey, Eurostat Comext - Statistical regime 4 . http://trade.ec.europa.eu/doclib/docs/2006/september/tradoc_1 13456.pdf, Accessed: 01.11.2017.

Fertö, I., Hubbard, L., 2003. Revealed comparative advantage and competitiveness in Hungarian agri-food sectors. World Economy, 26(2): 247-59.

Kovalčík, M., 2011. Profitability and competitiveness of forestry in European Countries. Journal of Forest Science, 57(9):369-76.

Krugman, P., 1994. Competitiveness: A dangerous obsession. Foreign Affairs, 73: 28-44.

Maksymets, O., Lönnstedt, L., 2016. International competitiveness: A case study of American, Swedish, and Ukrainian forest industries. The International Trade Journal, 30(2): 159-176.

Mercenier, J., Yeldan, E., 1997. On Turkey's trade policy: is a customs union with Europe enough? European Economic Review, 41(3-5): 871-880.

Ok, K., 2003. Küresel Liberalizasyonun Dünya Ve Türkiye Orman Kaynakları Açısından Sonuçları. IMF, Dünya Bankası Politikaları ve Doğal Kaynaklarımız, TMMOB, Ankara, ISBN: 975-395-594-4,

Prasad, R.N., 2004. Fiji's Export Competitiveness: A Comparison With Selected Small Island Developing States. Economic Department, Reserve Bank of Fiji.

Prestemon, J.P., Buongiorno J., Wear, D.N., Siry, J.P., 2003. International trade in forest products. In: Forests in a Market Economy (Eds: Sills, E.O., Abt, K.L.,) Forestry Sciences, 72, Springer, Dordrecht, pp.177-199.

Puttock, G.D., Sabourin, M., Meilke, K.D., 1993. International Trade in forest products: An overview. Forests Products Journal, Madison, 44(3): 49-56.

Siggel, E., 2006. International competitiveness and comparative advantage: A survey and a proposal for measurement. Journal of Industry, Competition and Trade, 6(2): 137-159.

Sirgmets, R., Teder, M., Kaimre, P., 2019. The structural changes and competitiveness of the forest and wood Sector in the Baltic Countries within 1999-2016. Baltic Forestry, 25(1): 97-104. 
Thornhill, D.J., 1988. The Revealed comparative advantage of Irish exports of manufacturers 1969-1982. Journal of the Statistical and Social Inquiry Society of Ireland, 25(5): 91-146.

United Nations, 2017. UN Comtrade Database - International Trade Statistics - Import/Export Data. http://comtrade.un.org, Accessed: 20.10.2017.

Uusivuori, J., Tervo, M., 2002. Comparative advantage and forest endowment in forest products trade: Evidence from panel data of OECD countries. Journal of Forest Economics, 8: 53-75.
Vollrath, T.L., 1991. A theoretical evaluation of alternative trade intensity measures of revealed comparative advantage. Weltwirtschaftliches Archiv, 127(2): 265-280.

Vollrath, T.L., Huu Vo, D., 1988. Investigating the nature of world agricultural competitiveness. Technical Bulletin. U.S Department of Agricultural, Economic Research Service, 1754: $10-11$.

Yılmaz, B., 2003. Turkey's Competitiveness in the European Union: a comparison with five candidate countries - Bulgaria, The Czech Republic, Hungary, Poland, Romania - and the EU15, Ezoneplus Working Paper,12, September 2003. 